\title{
Productivity and Cost of Integrated Harvesting of Wood Chips and Sawlogs in Stand Conversion Operations
}

\author{
Hunter Harrill and Han-Sup Han \\ Department of Forestry and Wildland Resources, Humboldt State University, 1 Harpst Street, Arcata, CA 95521, USA \\ Correspondence should be addressed to Hunter Harrill, hunter.harrill@pg.canterbury.ac.nz
}

Received 29 September 2011; Revised 25 November 2011; Accepted 14 January 2012

Academic Editor: Thomas V. Gallagher

Copyright (C) 2012 H. Harrill and H.-S. Han. This is an open access article distributed under the Creative Commons Attribution License, which permits unrestricted use, distribution, and reproduction in any medium, provided the original work is properly cited.

\begin{abstract}
This study evaluated the operational performance and cost of an integrated harvesting system that harvested sawlogs and biomass (i.e., energy wood chips) in stand conversion clearcut operations. Douglas-fir (Pseudotsuga menziesii) trees were processed into sawlogs while whole trees of tanoak (Lithocarpus densiflorus), and sub-merchantable materials (small-diameter trees, tops and limbs) were fed directly into a chipper to produce biomass for energy production. A standard time study method was used to determine productivity and costs. Over 26 working days, the integrated system produced 1,316 bone-dry metric tonnes (BDTs) of sawlogs, and 5,415.89 BDT of chips, with an average moisture content of 43.2\%. Using the joint products allocation costing method, the costs of the integrated system were $\$ 29.87 /$ BDT for biomass and \$4.26/BDT for sawlogs. Chipping utilization was as low as $41 \%$, directly affecting production and cost of chipping operation. Single-lane, dirt, spur roads were the most costly road type to transport whole trees to a centralized processing site: transportation costs for biomass and sawlogs were increased by $\$ 0.08 / \mathrm{BDT}$ and $\$ 0.02 / \mathrm{BDT}$, respectively, for every 50 meter increase in traveling distance. Diesel fuel price could raise total system cost for each product by $\$ 0.78 / \mathrm{BDT}$ and $\$ 0.08 / \mathrm{BDT}$ for each $\$ 0.10 /$ liter increase.
\end{abstract}

\section{Introduction}

On the north coast of California many once-commerciallyproductive conifer stands are now over-run by tanoak (Lithocarpus densiflorus), which sprouts from stumps, outcompeting merchantable conifer species. The transformation in species dominance from conifer to hardwood was the result of poor stocking success following earlier harvests. More than 16,187 hectares on private industrial forest land along the north coast of California are now classified silviculturally as rehabilitation stands due to understocking of conifers $\left(<11.49 \mathrm{~m}^{2}\right.$ of basal area per hectare; Figure 1) [1]. Converting stand composition through clearcut practices, referred to as rehabilitation harvests, has been taking place in northern California, but is expensive due to the large volume of nonmerchantable forest biomass which needs to be removed. If local bioenergy markets are available, nonmerchantable biomass could be converted into an energy wood product such as chips or hog fuel (i.e., ground woody biomass). However, forest biomass is often underutilized because collection and transportation costs are often greater than the market value of the materials [2].

Bioenergy is the largest source of renewable energy in the United States, with over 11 gigawatts of installed capacity [3]. Beckert and Jakle (2008) noted that $20 \%$ of all biomass used for bioenergy comes from the forestry sector, but improvements in the supply of feedstock is necessary to meet the demands of today's renewable energy development. Available woody biomass in the forest is not often utilized because of high costs associated with harvesting and transportation [4]. Improved knowledge on new and innovative systems used to harvest and remove woody biomass would aid land managers in the planning and execution of cost-effective bioenergy operations.

Integrated harvesting is defined as a single pass harvesting operation so that an energy component is produced in conjunction with conventional sawlog assortments [5]. Research has shown that integrated harvesting systems can be effectively used to harvest and supply woody biomass 


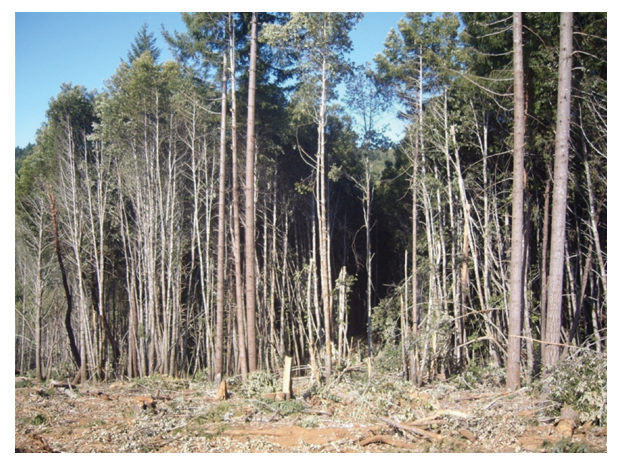

FIgURE 1: Tanoak dominated stand that was once a productive conifer stand, now managed through rehabilitation silviculture.

for energy from conventional forestry plantations [6]. Integration of biomass harvesting into an active logging operation could also reduce the cost of producing biomass by utilizing the equipment on site for multiple products and minimizing the amount of tree handling [7]. Since integrated harvesting removes biomass with sawlogs in a single pass, there is no need for a second operation to clean up harvesting residues. Integrated harvesting systems have been applied to fuel reduction thinning treatments to reduce the threat of forest fires. To reduce fuel loads in high density stands, whole trees are felled and removed to landings or roadsides where they are processed into sawlogs and biomass. This approach facilitates slash disposal without prescribed burning and increases opportunities for the utilization of biomass for energy production. Costs of integrated fuel reduction thinning operations have also been shown to be economically feasible at $\$ 25.79 / \mathrm{m}^{3}$ for sawlogs and $\$ 34.94 /$ BDT for biomass [8].

There are a variety of site conditions which favor integrated biomass harvesting operations. First, the sites to be harvested need to be readily accessible. Poor road surfacing, tight turns, and adverse grades should be improved prior to operations or avoided if possible. These conditions contribute to longer round-trip transportation times and higher transportation costs for vehicles with long lengths or low ground clearance (e.g., chip vans, log trucks hauling whole trees). Second, landing size at centralized processing sites should be sufficiently adequate for the flow of incoming material. If more than one harvest unit is storing material to a centralized processing site, several hectares may be required to store both biomass and sawlog products. Since there are multiple tasks happening with various schedules, centralized processing sites are often busy and need to safely accommodate multiple machines working on site. Addressing all of these conditions will aid in maximizing the production of biomass for bioenergy cost-effectively.

Delays are recognized as one of the major factors that limit chipping/grinding productivity in an integrated system and are an essential part of most time studies. Chipping utilization has been reported in a study relating to biomass harvesting operations at $73.8 \%$ [9]. Since utilization rates are correlated with production rates, lower utilization means lower daily production and higher unit production costs (\$/BDT). Ideally, one would aim to minimize chipping/grinding delays when planning an integrated harvesting operation, because it can be one of the most sensitive and expensive components of an operation.

This study evaluated the operational performance and cost of an integrated biomass harvesting system that harvested sawlogs and biomass (i.e., energy wood chips) in stand conversion clearcut operations. Specific objectives for this study were to determine the following.

(1) The hourly production rate for each stage of operation and the operation as a whole for both sawlog and biomass components.

(2) The unit production cost for each stage of operation and the operation as a whole for both products (\$/BDT).

(3) The major factors that affect the overall cost and productivity of the integrated biomass harvesting system.

\section{Material and Methods}

2.1. Study Sites. Three study units, with prescriptions for stand rehabilitation harvest, were located on private industrial forestlands in northern California. The composition of the three units ranged from 45 to $82 \%$ tanoak, 0 to $7 \%$ madrone (Arbutus menziesii), and 18 to $48 \%$ young growth Douglas-fir (Pseudotsuga menziesii), with slopes ranging from 0 to $45 \%$ (Table 1). The three stands ranged from six to nine hectares in area and were classified as understocked conifer stands ( $<11.49 \mathrm{~m}^{2} / \mathrm{ha}$ basal area of conifer stocking), except for Unit 2 which averaged $40.18 \mathrm{~m}^{2} /$ ha basal area of conifer stocking. Study units were cruised prior to operations with a systematic sampling grid $(31.7 \%$ of the total harvest area) of 0.08 ha per plot, with a minimum of two plots per hectare. Trees larger than $12.7 \mathrm{~cm}$ in diameter at breast height $(\mathrm{DBH})$ were recorded at each plot and used to estimate the preharvest stand volumes and average tree size.

All three units were clearcut with a mechanized groundbased shovel logging system. The integrated system utilized one Timbco T445D feller-buncher to cut and bunch whole trees at the site. Two Komatsu PC300 log loaders (Komatsu 1 \& Komatsu 2; Figure 2) were used to swing (i.e., shovel) bunches of whole trees to the roadside. Both loaders took turns loading roadside bunches of logs, whole trees, and tops onto two log trucks for transportation to a centralized processing site (Figure 2). The whole trees and residues delivered to the centralized processing site were immediately unloaded by another Komatsu log loader (Komatsu 3; Figure 2) which was equipped with a grapple saw, and worked with a remotely controlled pull-through delimber. The Komatsu log loader used for unloading was then also used to process sawlogs and sort nonsawlog (i.e., biomass) trees and residues for chipping.

All materials to be chipped were grappled by an adjacent Linkbelt 3400 swing loader and fed into a Morbark disk chipper. Chips were blown into a large pile on the ground, and then loaded by a Cat $962 \mathrm{G}$ front-end loader into 
At stump

Within harvest site

At roadside

Harvest site to processing site

At processing site

At processing site

At processing site

At processing site

Processing site to trailer yard

Final products

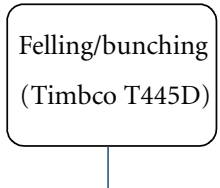

Shoveling (Komatsu 1 and 2)

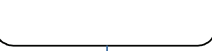

Loading (Komatsu 1 and 2)

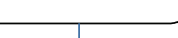

Hauling (2 log trucks)

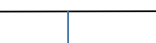

Unloading (Komatsu 3)

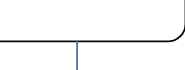

Sorting

(Komatsu 3)

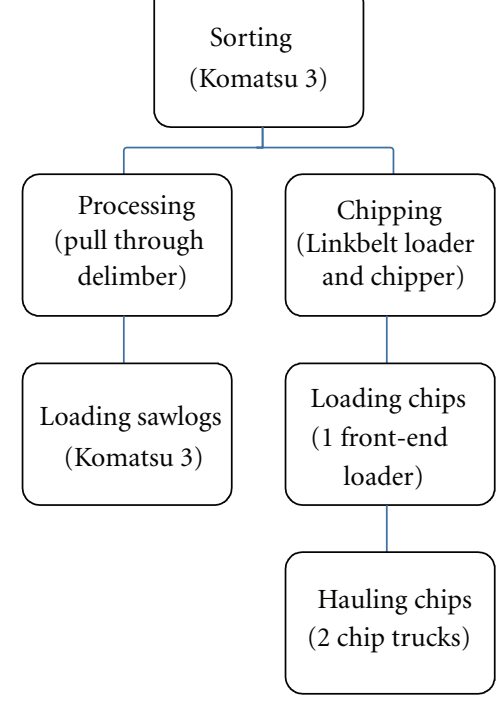

Sawlogs

Energy wood chips

(i.e. biomass)

FIGURE 2: Integrated harvesting and processing system flow chart.

TABle 1: Preharvest study unit descriptions.

\begin{tabular}{|c|c|c|c|c|c|c|c|c|c|c|c|c|c|c|}
\hline \multirow[b]{3}{*}{$\begin{array}{l}\text { Harvest } \\
\text { site }\end{array}$} & \multirow[b]{3}{*}{$\begin{array}{l}\text { Area } \\
\text { (ha) }\end{array}$} & \multicolumn{4}{|c|}{ Tanoak } & \multicolumn{4}{|c|}{ Douglas-fir } & \multicolumn{3}{|c|}{ Pacific madrone } & \multicolumn{2}{|c|}{ Total } \\
\hline & & \multicolumn{2}{|c|}{ Density } & \multicolumn{2}{|c|}{$\mathrm{DBH}$} & \multicolumn{2}{|l|}{ Density } & \multicolumn{2}{|c|}{$\mathrm{DBH}$} & \multirow{2}{*}{$\begin{array}{c}\text { Density } \\
\text { (stem/ha) }\end{array}$} & & \multirow{2}{*}{$\begin{array}{c}\text { DBH } \\
\text { lean S.D. }{ }^{a} \\
\text { centimeters) }\end{array}$} & \multirow{2}{*}{$\begin{array}{c}\text { Density } \\
\text { (stems/ha) }\end{array}$} & \multirow{2}{*}{$\begin{array}{c}\text { DBH } \\
\text { Mean S.D. }{ }^{\mathrm{a}} \\
\text { (centimeters) }\end{array}$} \\
\hline & & (stems/ha) & $\%$ & $\begin{array}{l}\text { Mean } \\
\text { (centir }\end{array}$ & $\begin{array}{l}\text { S.D. }{ }^{a} \\
\text { neters) }\end{array}$ & (stems/ha) & $\%$ & $\begin{array}{l}\text { Mean } \\
\text { (centir }\end{array}$ & $\begin{array}{l}\text { S.D. }{ }^{a} \\
\text { neters) }\end{array}$ & & $\%$ & & & \\
\hline Unit 1 & 9.30 & 84.81 & 82 & 25.68 & 10.97 & 18.65 & 18 & 29.92 & 11.13 & 0.35 & 0 & $15.24 \quad 0.00$ & & 25.5011 .10 \\
\hline Unit 2 & 6.07 & 51.08 & 45 & 28.47 & 16.51 & 54.14 & 48 & 27.53 & 13.46 & 7.54 & 7 & $30.96 \quad 23.04$ & 112.76 & $28.17 \quad 15.37$ \\
\hline Unit 3 & 6.88 & 136.92 & 74 & 23.83 & 7.11 & 48.79 & 26 & 33.05 & 13.36 & 0.22 & 0 & $78.74 \quad 0.00$ & 185.93 & $27.10 \quad 10.13$ \\
\hline
\end{tabular}

${ }^{\mathrm{a}}$ S.D.: standard deviation. 


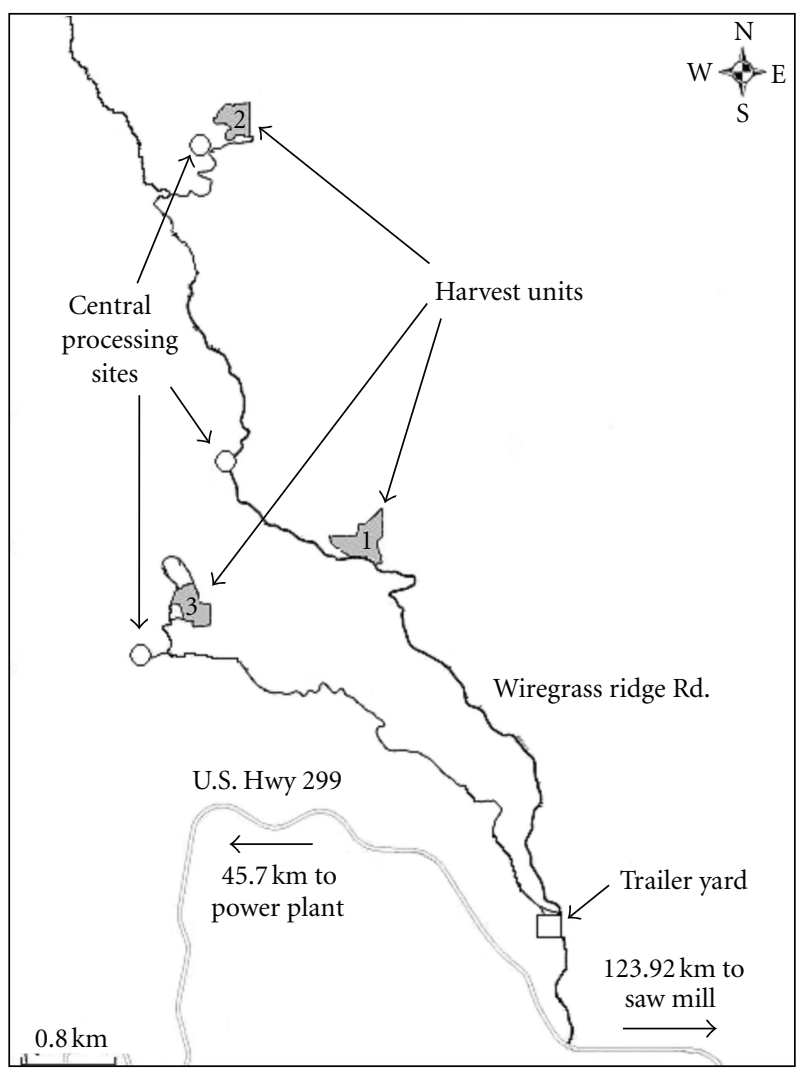

FIgURE 3: Operation layout map showing three harvest units with corresponding central processing sites. Whole trees and logs were hauled to the central processing sites to process and sort into biomass and sawlogs.

$13.72 \mathrm{~m}$ long chip trailers. The trailers were transported by two wood chip trucks, and staged approximately $6.5 \mathrm{~km}$ away at a trailer yard near the highway where many trailers were stored for further transportation to an energy plant $45.7 \mathrm{~km}$ away (Figure 3). Loaded trailers were traded at the yard for empty trailers and returned to the central processing site immediately in order to keep the chipper busy. A trucking company was hired to deliver the trailers from the trailer yard to the power plant, which took nearly two hours for a round trip at $45.7 \mathrm{~km}$ one-way distance. The staging of chip trailers at the trailer yard was necessary due to the limited space available at central processing sites. Sawlogs that were sorted and processed by the loader were decked at the centralized processing site, which loaded onto log trucks and delivered directly to the sawmill from the centralized processing sites more than $124 \mathrm{~km}$ one-way distance.

2.2. Measurement Protocol. Hourly machine costs in dollars per scheduled machine hour $(\$ / S M H)$ were calculated using standard machine rate calculation methods [10]. Delays were defined as all activities that do not directly contribute to the production of the operation. Purchase prices, salvage values, and all other necessary information for the standard machine rate calculation were obtained from the contractors who owned the equipment. Diesel fuel prices were determined from local market prices effective during the study period. All machinery was assumed to have a 10 -year economic life and work 1800 scheduled machine hours (SMHs)/year, except for the chipper which had a five-year economic life due to its extensive use.

Costs of each stage of operation and the operation as a whole were determined using the joint products allocation method [11]. Under this method, all stages of operations that produced both biomass and sawlogs apportioned their costs based on the contribution of each product to the total production. Costs associated with operational stages that produced a single product in its final form, or that only handled one product type, were charged solely to that product (e.g., chipping, loading sawlogs).

Activity sampling at the central processing site was observed over four of the 26 days of operation, sampling at fixed intervals of time (i.e., every 15 seconds for one hour, three times a day), to determine whether machines were working or not. Activity sampling data were collected over a relatively short period and were used to provide a glance at how well the machines and processes were matched at one particular centralized processing site. Through activity sampling, a better understanding could be gained of appropriate system balance by calculating individual machine utilization rates (ratio of $\mathrm{PMH}$ to SMH). Working at the central processing site was the Komatsu loader (Komatsu 3) which unloaded whole trees, sorted and delimbed trees, and loaded log trucks with saw logs. An adjacent Link Belt loader was used to feed biomass trees into the chipper, and the resulting chips were loaded into chip trailers with a front-end bucket loader.

Elemental time-motion data were recorded by a stop watch for each machine's cycle used in the harvesting system [12]. Cycle data were recorded for 10 hours a day, alternating between harvesting activities for a total of 26 working days. Regression equations were developed using Minitab 15 Statistical Software [13], through ordinary least squares estimators. To predict a machine's delay-free cycle time, average observed values for independent variables in the time study were entered into the developed regression equations. The following describe cycle elements for each harvesting activity phase.

(i) Felling/bunching started when the machine rotated or traveled empty to a tree followed by the cutting of the tree, then the machine rotated while loaded, and placed the tree in an existing pile or bunch, ending the cycle.

(ii) Shoveling (i.e., swinging logs and whole trees to roadsides) started when the machine rotated or traveled empty to a pile/bunch of trees, grappled the trees, rotated loaded to a new pile/bunch or road side, and ended when the machine dropped the trees or compacted them into another pile/bunch.

(iii) Loading (whole trees) started when the machine rotated or traveled empty to a pile/bunch of trees, grappled the trees, rotated loaded to the log truck, and ended when the trees were compacted onto bunks of the log truck. 
(iv) Hauling (whole trees) began when the truck traveled loaded along various roads to the central processing location, where it was unloaded, then traveled unloaded back to the harvest unit, and ended when the truck was finished being loaded with trees.

(v) Unloading at the centralized processing site started when the loader swung empty to the log truck, grappled the trees, rotated loaded to a pile/bunch of trees, and ended when the machine dropped the trees into a pile/bunch of trees.

(vi) Sorting/processing (sawlogs) started when the machine rotated empty toward the pile/bunch of trees, grappled the tree, followed by the tree being delimbed and or bucked/topped, rotated loaded to a pile of trees/logs, and ended when the tree/logs were placed on the pile.

(vii) Chipping started when the trees/tops were placed on the chipper's in-feed table and ended when the last chips dropped from the chipper's out-feed shoot.

(viii) Loading (biomass) started when the loader traveled empty to the pile of chips, followed by the chips being scooped into the loader's bucket, traveled loaded to the chip trailer, and ended when the last chips fell into the trailer from the loader's bucket.

(ix) Loading (sawlogs) started when the loader rotated empty to the deck of logs, grappled the logs, rotated back to the truck loaded, and ended when the loader placed the logs onto the truck's log bunks.

(x) Hauling (biomass chips) began when the truck traveled on in-woods roads to the trailer yard adjacent to the highway, unloaded the trailer, picked up an empty trailer, traveled back unloaded to the central processing site, and ended when the replacement trailer was filled with chips.

Average piece size for whole trees was calculated from preharvest stand cruise data, and scaled weights of chips (biomass) and sawlogs delivered to markets. The number of stems per hectare for each species at each harvest site was summed and divided by the scaled weights to calculate average tree weight. Samples of chipped material were collected in the morning, afternoon, and evening over four days of operation and dried in a laboratory oven to determine their moisture content, which was used to convert green tons to bone dry tons. The average tree weight was then converted to dry tons using moisture content data collected on site [14]. Moisture content was then used to predict the productivity in bone-dry tons (BDTs) for each process (felling, shoveling, loading, hauling to the central processing site, unloading/sorting, and chipping) of the operation that handled whole trees. The average volume and weight per tree removed was $0.66 \mathrm{~m}^{3}$ or $0.35 \mathrm{BDT}$. Chipped biomass weight was tracked by scaling ticket books from the local energy plant for every load. Log truck volume was tracked by ticket books obtained from the sawmill for every load, and both were averaged throughout the study.

Production rates (BDT/PMH) for each process were calculated using the delay-free cycle equations that were developed using detailed time study data. Average delay-free cycle times were estimated by entering average values for independent variables associated with a given cycle element into delay-free cycle equations to determine the $\mathrm{PMH}$ per cycle. The average number of trees recorded during the detailed time study was converted to BDT. Then weight per cycle was divided by the delay-free cycle time $(\mathrm{PMH})$ to yield a production rate $(\mathrm{BDT} / \mathrm{PMH})$.

\section{Results and Discussion}

3.1. Productivity of the Integrated Harvesting System. The integrated system was monitored for $260 \mathrm{SMH}$ over 26 working days during the summer of 2008. Throughout the study period, the system delivered 1,316 BDT of Douglas-fir sawlogs and 5,416 BDT of wood chips, which had an average moisture content of $43.2 \%$. The total system production rate was $35.26 \mathrm{BDT} / \mathrm{PMH}$, determined by the individual process with the lowest production rate (i.e., hauling chips).

The hauling of chips from central processing sites to the trailer yard yielded the lowest production of all stages of operations. A hauling cycle for chips took 43.9 minutes per round trip (Table 2 ). Round-trip times were highly influenced by traveling speeds associated with different road types. The distance in meters of single-lane dirt and spur (temporary road with unimproved surface) roads within the harvest unit were the variables that had the greatest effect on cycle time. The productivity of hauling whole trees from the harvest areas to the centralized chipping location (36.51 $\mathrm{BDT} / \mathrm{PMH}$ ), and for hauling chips from the centralized chipping area to the trailer yard (35.26 BDT/PMH), was the lowest of all phases of operation. Low production rates for hauling were most likely due to the slow traveling speeds observed on narrow forest roads ( 11 to $32 \mathrm{~km} / \mathrm{hr}$ ), and the long round trip distance of $2.80 \mathrm{~km}$ and $13 \mathrm{~km}$ for whole trees and chips, respectively.

The highest rates of production were achieved through the unloading of whole trees at the centralized processing sites. An average unloading cycle took only 3.46 minutes per truck (Table 2). The average production rate for unloading trees at the centralized processing site was $171.36 \mathrm{BDT} / \mathrm{PMH}$. The unloading of trees was most influenced by the number of grapples to lift the materials off the truck and the number of degrees that the machine rotated from the truck to the log deck. This rate was substantially different from the loading of trees (73.42 BDT/PMH) because it took less handling to remove a tree from the trucks than to carefully arrange them on the truck.

Activity sampling results indicated room for improvement in operational efficiency by balancing productivity between processes at one of the central processing sites. Again, this was based on only four days of sampling and may not be representative of the entire 26 days of operation. However, the sampled utilization rates are interesting to note as they show the potential changes in cost and production with relation to utilization rates. During activity sampling the chipper had an average utilization rate of $41 \%$, but at times was as high as $100 \%$. This translated to a low utilization 
TABLE 2: Regression equations that describe predicted delay-free cycle times in minutes for the integrated harvesting system.

\begin{tabular}{|c|c|c|c|c|c|c|}
\hline \multirow{2}{*}{ Process } & \multicolumn{5}{|c|}{ Independent variables } & \multirow{2}{*}{$\begin{array}{c}\text { Average delay-free cycle time } \\
\text { (minutes) }\end{array}$} \\
\hline & $\begin{array}{l}\text { Regression model for delay-free cycle } \\
\text { time }\end{array}$ & Mean & Range & $R^{2}$ & $n$ & \\
\hline \multirow{6}{*}{ Felling/bunching } & $=4.16$ & & & 0.66 & 766 & $0.52 /$ tree $(\mathrm{s})$ \\
\hline & +0.09 (no. trees) & 1.10 & $1-3$ & & & \\
\hline & $+0.03(\mathrm{DBH} \mathrm{cm})$ & 27 & $15-66$ & & & \\
\hline & +0.22 (loaded swing degrees) & 117 & $0-270$ & & & \\
\hline & +0.04 (no. grapples) & 0.30 & $0-10$ & & & \\
\hline & $+0.02($ travel distance $\mathrm{m})$ & 1.54 & $0-25$ & & & \\
\hline \multirow{7}{*}{ Shoveling } & $=3.81$ & & & 0.69 & 363 & $0.62 / \operatorname{tree}(s)$ \\
\hline & +0.18 (\%slope) & 20.29 & $5-50$. & & & \\
\hline & +0.37 (no. grapples) & 1.90 & $1-10$ & & & \\
\hline & +0.28 (loaded swing degrees) & 126 & $0-360$ & & & \\
\hline & +0.11 (no. trees) & 2.93 & $1-10$ & & & \\
\hline & +0.04 (no. compactions) & 0.55 & $0-11$ & & & \\
\hline & $+0.02($ travel distance $\mathrm{m})$ & 2.27 & $0-51$ & & & \\
\hline \multirow{6}{*}{ Loading (whole trees) } & $=4.60$ & & & 0.63 & 440 & $8.08 /$ truck \\
\hline & -0.13 (\%slope) & 10.19 & $5-35$ & & & \\
\hline & +0.41 (no. grapples) & 1.90 & $1-11$ & & & \\
\hline & +0.32 (loaded swing degrees) & 101 & $0-270$ & & & \\
\hline & +0.05 (no. compactions) & 0.98 & $0-7$ & & & \\
\hline & $+0.01($ travel dist $\mathrm{m})$ & 0.10 & $0-10$ & & & \\
\hline \multirow{3}{*}{ Hauling (whole trees) } & $=2592.8$ & & & 0.18 & 70 & $32.50 /$ trip \\
\hline & +0.12 (loaded spur distance $\mathrm{m}$ ) & 488.89 & 27-982 & & & \\
\hline & $\begin{array}{l}-0.01 \text { (loaded single land dirt road } \\
\text { distance } \mathrm{m} \text { ) }\end{array}$ & 13.41 & $0-117$ & & & \\
\hline \multirow{6}{*}{ Unloading } & $=4.00$ & & & 0.65 & 258 & $3.46 /$ truck \\
\hline & +0.48 (no. grapples) & 1.29 & $1-5$ & & & \\
\hline & +0.28 (loaded swing degrees) & 125 & $90-180$ & & & \\
\hline & +0.10 (no. pieces) & 3.42 & $1-12$ & & & \\
\hline & +0.04 (no. compactions) & 0.15 & $0-3$ & & & \\
\hline & $+0.01($ travel distance $\mathrm{m})$ & 0.14 & $0-15$ & & & \\
\hline \multirow{6}{*}{$\begin{array}{l}\text { Sorting/processing } \\
\text { (sawlogs) }\end{array}$} & $=4.02$ & & & 0.65 & 311 & $0.66 /$ tree $(\mathrm{s})$ \\
\hline & +0.53 (no. grapples) & 2.10 & $1-10$ & & & \\
\hline & +0.20 (loaded swing degrees) & 125 & $90-360$ & & & \\
\hline & +0.14 (no. pieces) & 2.26 & $1-15$ & & & \\
\hline & +0.02 (no. compactions) & 0.39 & $0-5$ & & & \\
\hline & +0.01 (travel distance $\mathrm{m})$ & 0.55 & $0-15$ & & & \\
\hline \multirow{3}{*}{ Chipping } & $=2.32$ & & & 0.22 & 117 & $0.44 /$ tree $(\mathrm{s})$ \\
\hline & -0.42 (no. trees) & 1.79 & $1-6$ & & & \\
\hline & $+1.83(\mathrm{DBH} \mathrm{cm})$ & 28 & $15-76$ & & & \\
\hline \multirow{3}{*}{ Loading (biomass) } & $=1.83$ & & & 0.47 & 375 & $5.84 /$ truck \\
\hline & +0.04 (no. scoops) & 0.99 & $0-3$ & & & \\
\hline & +0.20 (travel loaded distance $\mathrm{m})$ & 23 & $0-80$ & & & \\
\hline \multirow{5}{*}{ Loading (sawlogs) } & $=3.82$ & & & 0.49 & 107 & $9.22 /$ truck \\
\hline & -1.06 (loaded swing degrees) & 108 & $90-180$ & & & \\
\hline & +1.12 (empty swing degrees) & 110 & $90-180$ & & & \\
\hline & +0.28 (no. grapples) & 1.64 & $1-5$ & & & \\
\hline & +0.03 (no. compactions) & 0.76 & $0-6$ & & & \\
\hline
\end{tabular}


TABle 2: Continued.

\begin{tabular}{|c|c|c|c|c|c|c|}
\hline \multirow{2}{*}{ Process } & \multicolumn{5}{|c|}{ Independent variables } & Average delay-free cycle time \\
\hline & $\begin{array}{l}\text { Regression model for delay-free cycle } \\
\text { time }\end{array}$ & Mean & Range & $R^{2}$ & $n$ & (minutes) \\
\hline \multirow{3}{*}{ Hauling (biomass) } & $=615.35$ & & & 0.79 & 46 & $43.87 /$ trip \\
\hline & $\begin{array}{l}\text { +0.05 (loaded primary dirt road distance } \\
\text { m) }\end{array}$ & 5,260 & $0-6,807$ & & & \\
\hline & $\begin{array}{l}+0.06 \text { (loaded secondary dirt road } \\
\text { distance } \mathrm{m} \text { ) }\end{array}$ & 1,129 & $0-5,071$ & & & \\
\hline
\end{tabular}

$n$ : number of observed cycles.

rate of $49 \%$ for the loader (Linkbelt) which fed the chipper and $43 \%$ for the front-end loader which loaded the chips into trailers, because these machines were dependent upon one another. The Komatsu loader (Komatsu 3) had the greatest utilization rate $(74 \%)$ at the processing site, because the machine had three tasks of unloading, sorting/processing, and loading sawlogs. Log trucks hauling whole trees were utilized to nearly their full potential (96\%) which indicated the need for an additional log truck to keep the processing site busy. However, introducing another log truck into the system would require additional feller-bunchers and loaders at the harvest unit to keep up with trucking over the short round trip hauling distance of $2.80 \mathrm{~km}$. Hauling of biomass chips had a relatively low utilization rate (69\%) which was primarily a result of low productivity (BDT/PMH) of chipping. If chipping production was to increase, additional trucks would be needed for the long round-trip cycle ( 43.87 minutes) (Table 2) from the processing site to the trailer yard adjacent to the highway.

3.2. Costs for Harvesting Both Sawlogs and Biomass. Machine rates, production rates, and production costs for each stage of operation, and the operation as a whole, are summarized in Table 3. The total hourly system cost of running all the machines used in the integrated harvesting operation was $\$ 1,936.76 / \mathrm{PMH}$, which included ownership, operating, and labor costs. When applying production rates for each harvesting process, the most expensive system process was found to be chipping (\$9.94/BDT). This was due to the low production rate $(47.18 \mathrm{BDT} / \mathrm{PMH})$ in relation to the high machine rate $(\$ 468.78 / \mathrm{PMH})$ for two machines: the chipper and the loader that feeds it. Using the joint products allocation method, the total unit production costs from the integrated system were $\$ 29.87 / \mathrm{BDT}$ for biomass and $\$ 4.26 / \mathrm{BDT}$ for sawlogs. These total system costs do not include the costs associated with supporting machinery (fuel, water, maintenance, and personnel trucks), profit margin, move-in, or transportation of products in their final form to markets.

Machines used throughout system processes were all assumed to have a utilization rate of $85 \%$ as suggested by Miyata (1980) [10]. Activity sampling at one central processing site was used to demonstrate how these utilization rates can change by site or when system balance is not ideal. For example, the observed utilization rate for chipping, as indicated through the four days of activity sampling, was

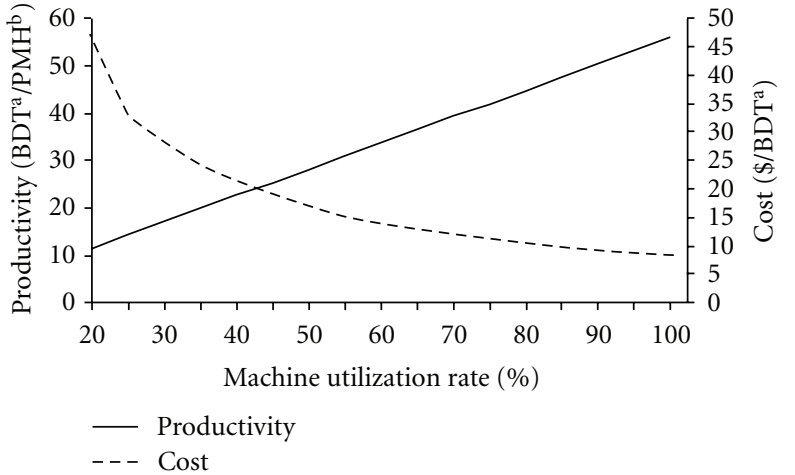

FIGURE 4: Cost and productivity of whole tree chipping with various utilization rates for associated machinery. ( ${ }^{a} B D T$ : bone dry metric tons; ${ }^{b} \mathrm{PMH}$ : productive machine hour; $\mathrm{SMH}$ : scheduled machine hour; Utilization $=(\mathrm{PMH} / \mathrm{SMH}) * 100)$.

$41 \%$. The low observed utilization rate would translate to reduced production and higher costs than those calculated in Table 3. Figure 4 shows the possible production rates and costs of chipping if the machines involved were operating at utilization rates of less than $85 \%$. The linear relationship between production and utilization rate should be noted. Increasing the utilization rate by only $10 \%$ can raise chipping production by $5.55 \mathrm{BDT} / \mathrm{SMH}$. The relationship between cost and utilization rate, on the other hand, is quite different; chipping costs were as low as $\$ 9.94 / \mathrm{BDT}$ when utilization was $85 \%$ and as high as $\$ 20.60 / \mathrm{BDT}$ when utilization rates fell to $41 \%$. In this sensitivity analysis, more than $\$ 1 / \mathrm{BDT}$ for every $5 \%$ increase in chipping utilization rate could be saved, until the rate reaches $70 \%$. Thereafter, the savings would be less than $\$ 1 / B D T$. Having a high utilization rate is important since chipping is one of the most expensive stages of operation, and because production in any following stages of operation is often influenced by chipping. Having a high utilization rate will also increase productivity and reduce costs, saving money for the other stages of operation like collection and transportation. It is ideal to maximize utilization rates of all machines and processes involved in integrated systems. Potential savings could be as high as $\$ 32.05 / \mathrm{BDT}$ for biomass and $\$ 4.58 / \mathrm{BDT}$ for sawlogs, if all machines in the system operated at a balanced utilization rate of $85 \%$ compared to $41 \%$ observed during activity sampling (Figure 5). 
TABLE 3: Harvesting system productivity and costs in the integrated harvesting system.

\begin{tabular}{|c|c|c|c|c|c|}
\hline \multirow{2}{*}{ Process } & \multirow{2}{*}{$\begin{array}{l}\text { Cycle time } \\
\text { (minutes) }\end{array}$} & \multirow{2}{*}{$\begin{array}{c}\text { Production rate } \\
\left(\mathrm{BDT}^{\mathrm{a}} / \mathrm{PMH}^{\mathrm{b}}\right)\end{array}$} & \multirow{2}{*}{$\begin{array}{c}\text { Machine rate } \\
\left(\$ / \mathrm{PMH}^{\mathrm{b}}\right)^{\mathrm{c}}\end{array}$} & \multicolumn{2}{|c|}{ Joint products cost $\left(\$ / \mathrm{BDT}^{\mathrm{a}}\right)$} \\
\hline & & & & (sawlogs) & (biomass) \\
\hline Felling/bunching & 0.52 & 44.69 & 188.24 & 0.84 & 3.37 \\
\hline Shoveling & 0.62 & 99.13 & 176.47 & 0.36 & 1.42 \\
\hline Loading & 8.08 & 73.42 & 176.47 & 0.48 & 1.92 \\
\hline Hauling & 32.50 & 36.51 & 211.76 & 1.16 & 4.64 \\
\hline Unloading & 3.46 & 171.36 & 130.62 & 0.15 & 0.61 \\
\hline Sorting & 0.66 & 71.29 & 138.36 & 0.39 & 1.55 \\
\hline Chipping & 0.44 & 47.18 & 468.78 & 0.00 & 9.94 \\
\hline Loading (biomass) & 5.84 & 132.36 & 121.48 & 0.00 & 0.92 \\
\hline Loading (sawlogs) & 9.22 & 147.67 & 130.62 & 0.88 & 0.00 \\
\hline \multirow[t]{2}{*}{ Hauling (biomass) } & 43.87 & 35.26 & 193.96 & 0.00 & 5.50 \\
\hline & & Total & 1936.76 & 4.26 & 29.87 \\
\hline
\end{tabular}

${ }^{\mathrm{a}}$ BDT: bone dry metric ton.

bPMH: productive machine hours.

c $\$ / \mathrm{PMH}$ : machine rates were calculated using the assumptions of 33\% fringe benefits, $10 \%$ interest, and $2 \%$ insurance.

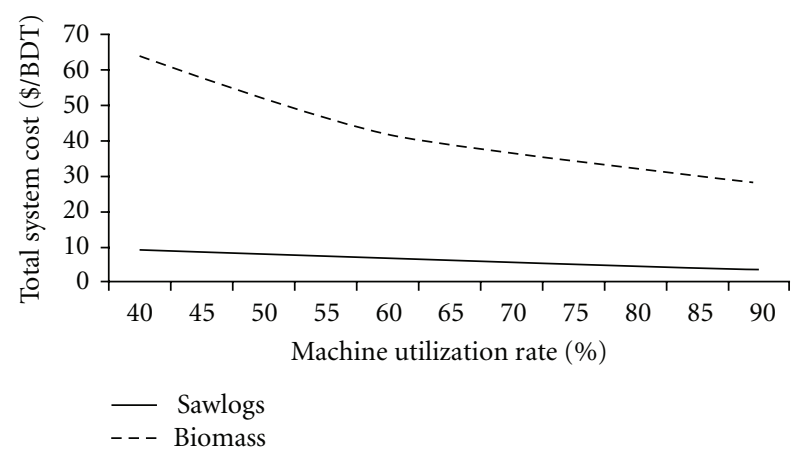

Figure 5: Total system cost for producing biomass in an integrated harvesting system based on varying machine utilization rates.

Transportation of whole trees on log trucks yielded one of the lowest productivities of all stages of operation that handled both products $36.51 \mathrm{BDT} / \mathrm{PMH}$ and was the most expensive stage of operation for the production of sawlogs $(\$ 1.16 / \mathrm{BDT})$ (Table 3). This was due to low traveling speeds on forest roads $(<12 \mathrm{~km} / \mathrm{hr})$ caused by poor road conditions, including rough road surface with no gravel, single lane road width, steep road grades, and sharp curves. In this study, the average round trip distance was only $2.80 \mathrm{~km}$ but took 32.5 minutes without delays.

There was a noticeable relationship between whole tree hauling costs and whole tree one-way hauling distances with relation to road type. Every 50 meter increase of spur road was proportional to a $\$ 0.08 / \mathrm{BDT}$ and $\$ 0.02 / \mathrm{BDT}$ increase in the cost of hauling for biomass and sawlogs, respectively. It should be noted how the increased use of mainline (twolane gravel road) or one-and-a-half lane width improved dirt roads in proportion to spur roads can reduce total hauling costs. This relationship between reduction of cost with increased mainline road distance was due to the higher

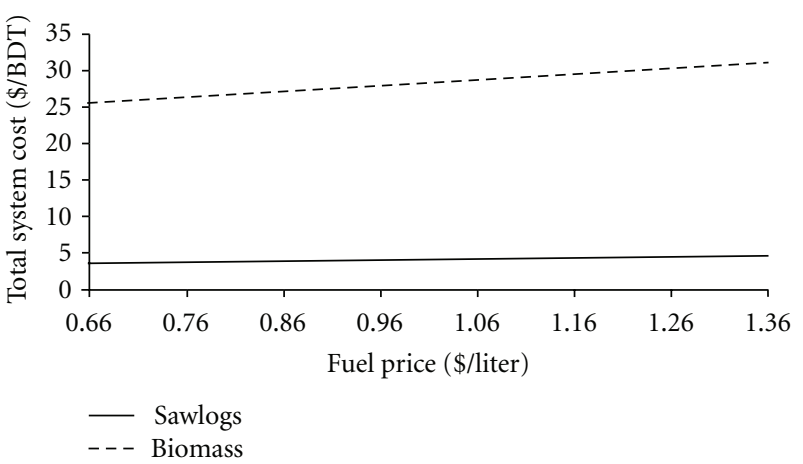

Figure 6: Total system production cost associated with various diesel fuel prices.

traveling speeds $(26 \mathrm{~km} / \mathrm{hr})$ observed along higher quality road types.

Diesel fuel prices reached a peak at $\$ 1.21 /$ liter in the region during the course of operations in the summer of 2008 and then steadily declined to $\$ 0.66 /$ liter six months after commencement of operations. Fuel costs had a greater influence on cost per unit of product in an integrated harvesting operation, due to the high fuel consumption rate of machinery. The integrated harvesting operation in this study consisted of 11 machines, including the chipper which had the greatest fuel consumption rate of 113 liters per hour. Holding all other variables constant, every $\$ 0.10 /$ liter increase in fuel price is equivalent to an increase of $\$ 0.78 / \mathrm{BDT}$ and $\$ 0.08 / \mathrm{BDT}$ in total system production cost for biomass and sawlogs, respectively (Figure 6).

\section{Conclusion}

During 26 days of operations, the integrated harvesting system produced and delivered 1,316 BDT of sawlogs and 5,416 BDT of chips, with an average wet-based moisture 
content of $43.2 \%$. The total cost for the integrated system was $\$ 1,936.76 / \mathrm{PMH}$ and produced Douglas-fir sawlogs at a cost of $\$ 4.26 / \mathrm{BDT}$, while chipping nonmerchantable size material and species into energy wood chips at a cost of $\$ 29.87 / \mathrm{BDT}$. Hauling chips to the trailer yard adjacent to the highway was the least productive stage of the entire operation at 35.26 $\mathrm{BDT} / \mathrm{PMH}$. The highest rates of production were achieved through the unloading of whole trees at the centralized processing sites. Round trip transportation distances averaged $2.80 \mathrm{~km}$ for hauling whole trees from the harvest units to the centralized processing sites, and $13.0 \mathrm{~km}$ for hauling biomass chips from the centralized processing sites to the trailer yard adjacent to the highway. Loaded trailers were traded at the trailer yard for empty trailers, which were then transported to a local energy plant approximately $45.7 \mathrm{~km}$ away by a contracted trucking service.

The results of activity sampling indicated some room for improvement in balancing productivity between components in the integrated harvesting system. There were four machines working simultaneously at the processing, but not all machines were working at the same production rate. The most expensive process of chipping $(\$ 468.78 / \mathrm{PMH})$ was found to have a utilization rate of only $41 \%$ during activity sampling. Ideally, machines should be paired to adjacent operational phases and machinery with similar production rates in an attempt to maximize their individual utilization rates. This can increase potential productivity and decrease production costs.

Sensitivity analysis evaluated how machine utilization rates, road hauling distances, and diesel fuel costs can affect system costs. Raising the utilization rate of the chipper by only $10 \%$ is equivalent to a $5.55 \mathrm{BDT} / \mathrm{PMH}$ increase in production. Every 5\% increase in utilization results in a cost savings of $\$ 1 / \mathrm{BDT}$, until $70 \%$ utilization, where it decreases thereafter. Transportation costs were found to be the most expensive stage of operation, which is correlated with hauling distance and road quality. Ideally, the use of single-lane dirt spur roads should be minimized due to their slow associated travel speeds, with every 50 meters producing a $\$ 0.08 / \mathrm{BDT}$ and $\$ 0.02 / \mathrm{BDT}$ increase in hauling cost for biomass and sawlogs, respectively. Diesel fuel prices are often overlooked in harvesting operations but can have a substantial effect on total system production cost. This is especially true when using a chipper, which consumes more than 113 liters/hr. Each 10 cent increase in diesel fuel price per liter represents a $\$ 0.78 / \mathrm{BDT}$ or $\$ 0.08 / \mathrm{BDT}$ increase in total system production cost for sawlogs and biomass, respectively.

Careful planning of integrated harvesting systems, such as this one, should take into account conditions between harvest units and processing sites, and appropriate pairings and number of machines, in order to maximize production. System balance is essential in order to match production levels of different system processes, thereby minimizing congestion and improving efficiency. These concepts are typical of most operations but become especially important during integrated harvests, due the large amount of personnel and machinery in use, the dependency of operational phases, and the complexity of producing more than one product.
The integrated harvesting of biomass and sawlogs in stand conversion operations was cost-effective. Previously understocked conifer stands with large nonmerchantable hardwood components were removed and planted back to productive conifer stands. Forest residues were successfully removed without prescribed burning. Additionally, costs associated with the biomass harvesting operation were minimized by best utilizing machinery on site to produce both biomass and sawlog products. Finally, the most exciting outcome of the stand conversion operation and integrated harvesting system was the clean renewable energy produced. The nearby biomass power plant converted the wood chips into electricity, which supplied homes and businesses across the region.

\section{References}

[1] M. W. Alcorn, Forester, Personal Communication, Green Diamond Resource Company, Korbel, Calif, USA, 2008.

[2] R. Withycombe, "Estimating costs of collecting and transporting forest residues in the northern Rocky Mountain Region," Tech. Rep. INT-81, USDA Forest Service, Intermountain Forest and Range Experiment Station, Ogden, Utah, USA, 1982.

[3] E. Beckert and A. Jakle, Renewable Energy Data Book, U.S. Department of Energy, Energy Efficiency and Renewable Energy, 2008.

[4] H. S. Han, H. W. Lee, and L. R. Johnson, "Economic feasibility of an integrated harvesting system for small-diameter trees in southwest Idaho," Forest Products Journal, vol. 54, no. 2, pp. 21-27, 2004.

[5] J. B. Hudson, C. P. Mitchell, and P. G. S. Storry, "Costing integrated harvesting systems," in Proceedings of the IEA/BA Task 6th Activity Integrated Harvesting Systems, J. B. Hudson, Ed., vol. 2, pp. 46-52, Aberdeen University Foestry Research Paper, Copenhagen, Denmark, May 1990.

[6] C. P. Mitchell, J. B. Hudson, D. N. A Gardner, P. G. S. Storry, and I. M. Gray, Wood Fuel Supply Strategies, vol. 1 of ETSU B1176-P1, Energy Technology Support Unit, Harwell, UK, 1990.

[7] C. Rawlings, B. Rummer, C. Seeley et al., A Study of How to Decrease the Costs of Collecting, Processing and Transporting Slash, Montana Community Development Corporation, Missoula, Mont, USA, 2004.

[8] S. Largo and H.-S. Han, "Economics of and integrated harvesting system in a fuel reduction thinning in western Montana," in Proceedings of the Council On Forest Engineering (COFE) Meeting, p. 6, Hot Springs, Ark, USA, July 2009.

[9] R. Spinelli and R. J. M. Visser, "Analyzing and estimating delays in wood chipping operations," Biomass and Bioenergy, vol. 33, no. 3, pp. 429-433, 2009.

[10] E. S. Miyata, "Determining fixed and operating costs of logging equipment," Tech. Rep. NC-55, USDA Forest Service, North Central Forest Experiment Station, St. Paul, Minn, USA, 1980.

[11] G. D. Puttock, "Estimating cost for integrated harvesting and related forest management activities," Biomass \& Bioenergy, vol. 8, no. 2, pp. 73-79, 1995.

[12] E. D. Olsen, M. N. Hossain, and M. E. Miller, Statistical Comparison of Methods Used in Harvesting Work Studies, vol. 23, Oregon State University, Forest Research Laboratory, Research Contribution, 1998. 
[13] Minitab StatGuide, Version 15, Minitab Inc., State College, Pa, USA, 2006.

[14] W. T. Simpson, "Drying and control of moisture content and dimensional changes," in Wood Handbook: Wood as an Engineering Material, General Technical Reports FPL-GTR113, pp. 12-1-12-20, USDA Forest Service, 1999. 

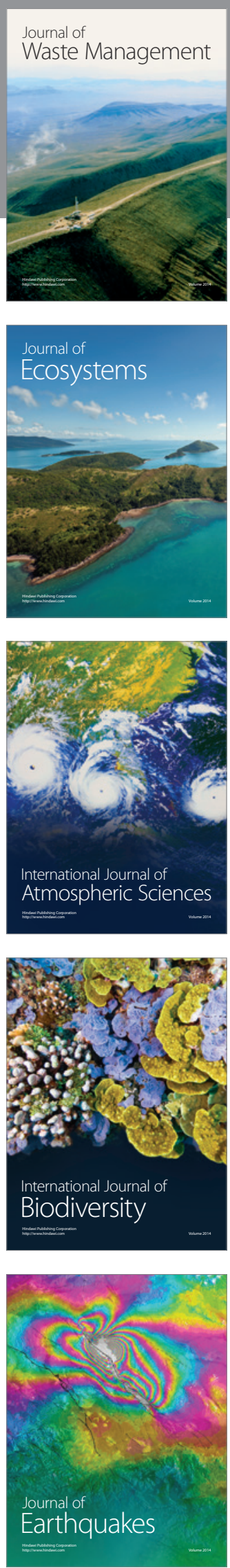
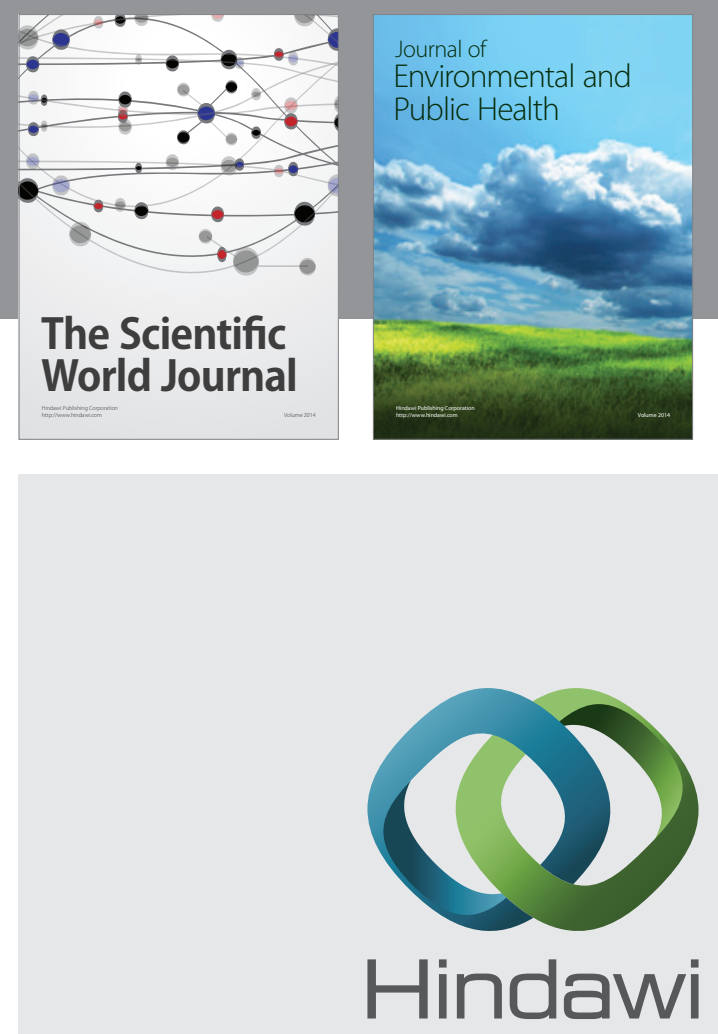

Submit your manuscripts at

http://www.hindawi.com
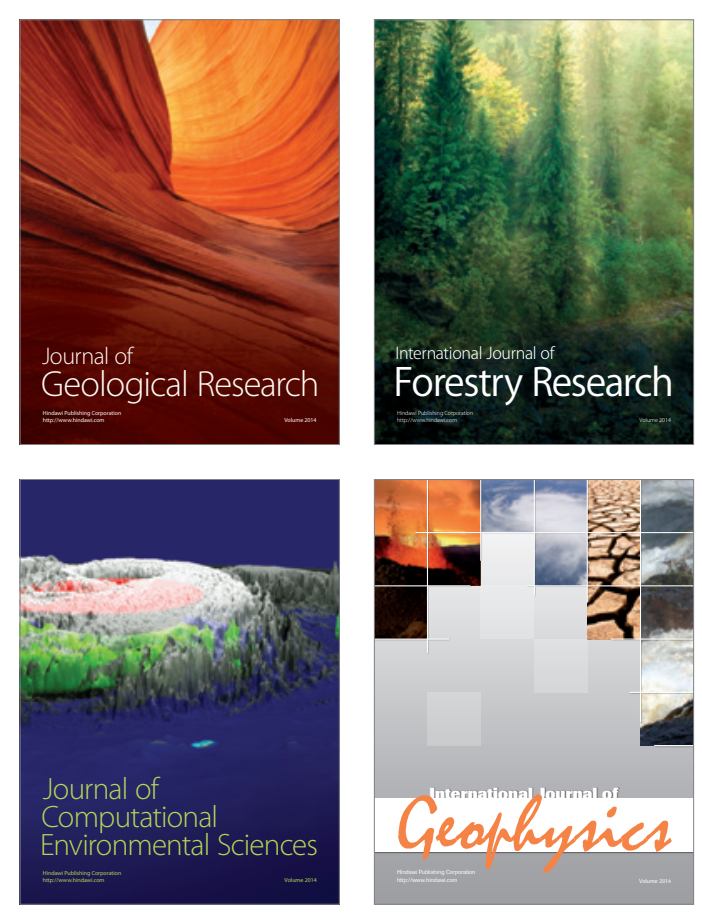
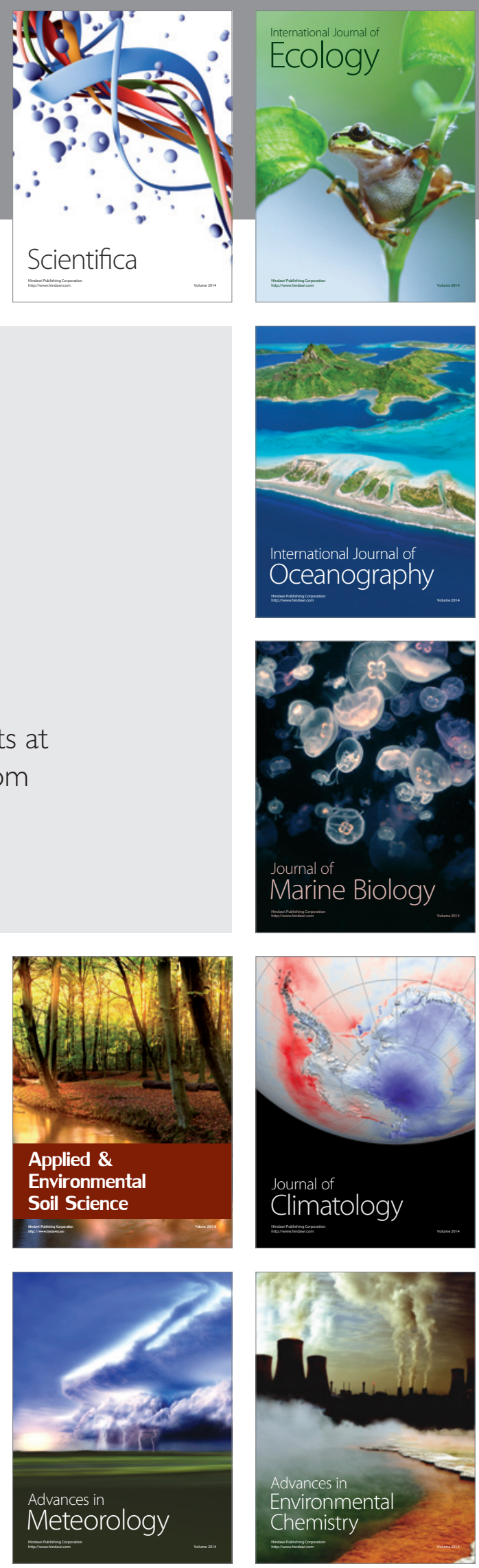